\title{
Introduction: Contested Competences in the European Union
}

\author{
HENRY FARRELL and ADRIENNE HÉRITIER
}

In this article, we set out an approach to European Union politics that seeks to explain its development using theories of institutional change. In contrast to dominant theories which assume that the Treaties, the governing texts of the European Union, faithfully ensure that the desires of member states are respected, we argue that these theories are incomplete contracts, rife with ambiguities. This means that during periods between Treaty negotiations, we may expect that collective actors in the European Union policy process - the European Commission, the European Parliament and the Council - will each seek to bargain over these ambiguities so that their effective competences are maximised. Their ability to negotiate successfully will depend on their bargaining strength. These 'conflicts over competences' may lead to the creation of informal institutions. They may also in the longer term lead to formal institutional change, if they become folded into Treaty texts, or otherwise influence them, in subsequent rounds of negotiation.

What are the sources of change in institutional settings such as the European Union? This question is at the heart of important debates in both comparative politics and international relations. In the study of the EU, an influential body of scholarship has argued that the Treaty texts, the underlying 'constitution' of the EU, fully reflect the intentions of their drafters. Member states create the correct incentives for the other actors, the Commission, Parliament, to act according to the formers' preferences (Moravcsik 1998; Tsebelis and Garrett 2001). Change, when it occurs, reflects changes in the underlying constellation of member state interests.

In this volume, we set out to challenge this set of arguments and to show how change may be driven by conflicts between the Council, Parliament and Commission over their respective competences within the legislative and policy-making process in the period between formal Treaty changes. Not only does the argument that Treaty texts faithfully implement member state interests seem at odds with much of the existing empirical evidence; it implicitly rests on the contestable theoretical assumption that the principals in complex principal-agent relationships can draft complete contracts which 
will cover all contingencies. In this article, we argue the contrary - that the Treaty texts are better considered as incomplete contracts, which do not cover all contingencies. Their provisions frequently are ambiguous and, therefore, are renegotiated by Council, Commission and Parliament in the day-to-day process of legislative decision-making. When unforeseen contingencies occur, actors may seek to use their bargaining leverage to ensure that the Treaties are interpreted in a way that maximises their control over the legislative process over the longer term.

Two forms of Treaty ambiguity are especially important. First, the Treaty may allow for the application of any of several possible procedures of choice (legislative procedures such as codecision, or comitology procedures) in a given instance. Second, the Treaty texts themselves will very frequently be obligationally incomplete - that is, they will not spell out precisely the respective competences and obligations of the different actors involved - so that the process of specifying them will involve the creation of new interstitial rules. These rules may be informal (Farrell and Héritier 2003) ${ }^{1}$ or formal (for example rulings of the European Court of Justice - ECJ) and serve to reduce ambiguity. In other words, Treaty rules may prove more difficult or complex to implement ex post than they appear ex ante. This will give rise to conflicts of interpretation, in which the distinct bargaining strength of actors will be instantiated in expectations over outcomes and thus, over time, in patterns of choice over existing institutional rules or in the emergence of new informal institutions.

In short, then, institutional change will not occur only as a result of exogenous change in the interests of the member states. It will also occur through endogenous processes of bargaining among the Council, Commission and Parliament as they make laws and regulations together. Furthermore, these changes at the informal level and at the level of procedural politics, i.e. selection among multiple possible lower order formal rules, may later lead to formal Treaty change, i.e. change of higher order rules. Because the procedures for Treaty change require unanimity, it will, in practice, prove extremely difficult for member states to reverse these processes of informal institutional change ex post through subsequent Treaty revision. Indeed, as we show, the member states may not only sometimes find it advantageous to accept these changes as faits accomplis, but may formalise them in order to lower transaction costs, thus leading to Treaty change.

Thus, we may expect that, over the longer term, both the formal and informal interstitial institutional development of the EU will deviate in important ways from the initial intentions of the collectivity of member states. Most particularly, we predict that conflicts over competences between the key actors in the legislative process will be a key driver of institutional change. As actors bargain with each other over how this or that ambiguous provision of the Treaty should be interpreted or over which of one of several possible procedures of decision-making should be chosen, new formal and informal institutions are created which may have repercussions for future rounds of 
formal Treaty revisions. Thus, shifts in power between actors over decisionmaking between formal rounds of Treaty revision may have important consequences. ${ }^{2}$ In this article, we present an incomplete contracting approach to interstitial institutional change in the EU, which specifies the mechanisms through which institutional change occurs and produces some initial hypotheses. We conclude by discussing the specific contributions of the articles in this volume to understanding institutional change in the EU.

\section{Conflict over Competences in the EU}

The argument that political actors in fluid institutional settings will strive to maximise their competences, and that this will have important political consequences, is hardly original. Nonetheless, it has received less attention than it deserves in the study of relations among political actors in the EU. Traditional debates in EU studies have revolved around whether EU integration reflects the desires of EU member states, as argued by intergovernmentalists, or, alternatively, whether the EU has somehow escaped the control of its creators, as argued by neo-functionalists among others. These debates have not usually examined the micro-motivations of actors in any great detail. More recent discussions in EU studies have focused on metatheory and the respective contributions that rational choice and constructivism can play in explaining EU politics (Jupille et al. 2003). While constructivists have eschewed discussion of clashes of interest and focused on broader structural forces or on 'thick' persuasion and socialisation, rationalists have underplayed the role of strategic bargaining over competences within the EU. ${ }^{3}$ In particular, in a recent landmark article in EU studies, George Tsebelis and Geoffrey Garrett argue that 'the institutional interactions we analyze [those affecting the balance of power between the Commission, Council, Parliament and European Court of Justice]... generally reflect the collective will of the member governments concerning their desired trajectory for the evolution of the EU' (Tsebelis and Garrett 2001: 360). Andrew Moravcsik (1997), for his part, argues that there are no substantial unintended consequences in EU decision-making. In making such claims, these scholars insulate the process of institutional creation (which they attribute to the member states in Inter-Governmental Councils) from the dayto-day political interactions that take place within these institutions. They therefore exclude by fiat the possibility that institutional change may take place through day-to-day bargaining over competences between Council, Commission and Parliament. The contributions in this volume theorise how such institutional change may occur and show that it does occur.

First, as previously stated, the Treaty texts are best considered to be incomplete contracts. Here we build both on Paul Pierson's (1996) work on unintended consequences, and on Simon Hix's (2002) previous account of the incompleteness of the EU Treaty texts. Economists typically define incomplete contracts as agreements that are insufficiently state-contingent; 
that is, contracts 'that fail to realize fully the potential gains from trade in all states of the world' (Ayres and Gertner 1992: 730). Legal scholars, in contrast, focus on how contracts are likely to be obligationally incomplete that is, how they do not fully specify the obligations that each actor holds. The latter form of incompleteness rests on the assumption that actors are only boundedly rational. Jean Tirole (1999: 741-2) notes that 'the organization of political life' is a 'case in point' of how contracts only incompletely spell out obligations in the latter sense of the term:

In the executive, ministries and agencies are given loose objectives. No mention is made of the many contingencies that may determine the ministry's desirable choices and of how decisions are to react to these contingencies. Similarly, the legislative branch of the government is set up as a distribution of agenda setting powers, voting rights, and checks and balances between houses rather than as a contract specifying how public decisions follow from the elicitation of information about the economy and society.

As Kenneth Shepsle (1989: 141) acknowledges, this poses a key challenge for accounts of politics that take institutions as a given:

In general, what can be anticipated in advance is that there will be unforeseen contingencies. Many institutions with which we are familiar, anticipating this, possess short-circuiting procedures... Yet, for the most part, the theories discussed in preceding paragraphs (with some exceptions) conceive of institutions as ex ante bargains - as the one-time-only choice of a game-form.

In this volume, we take Tirole's (1999) and Shepsle's (1989) emphasis on the incompleteness of institutions as our starting point, and argue that Treaty texts will be obligationally incomplete, and only imperfectly spell out the respective obligations of actors in the legislative and policy-making process. ${ }^{4}$ While the member states play a key role in the political process through revising the Treaty texts, they do not and cannot have sufficiently foresight to anticipate all eventualities. They may be able to remedy mistakes and close loopholes - but under current rules they need to reach unanimity among themselves to do this. To adopt Oliver Williamson's (1975) terminology, the 'remediability' of mistakes made by the member states depends on the decision rule that they adopt; and many mistakes will be difficult, or impossible, for them to remedy under the unanimity requirement for Treaty change.

Further, we assume that actors within the EU will wish to maximise their competences. Given that the Treaty texts may only ambiguously spell out actors' competences, actors can potentially increase their effective competences if they are able to bargain successfully or alternatively see their competences curtailed if they have insufficient bargaining strength. 
The assumption that actors are competence maximisers is highly plausible in a polity such as the EU which has been in a continuous ferment of institutional change for two decades. The long-term stakes for actors in terms of control of political resources are especially high (Farrell and Héritier 2003). Given that the Treaty texts are incomplete and ambiguous, each organisational actor will seek to ensure that these texts are interpreted in such a way as to maximise its own competences over law-making.

Thus, we contend that in a situation where contracts are incomplete and actors are competence maximisers, institutional development will occur not only at the initial moment of institutional choice, but also in ex post bargaining among actors over how ambiguities in institutions should be interpreted. In the latter, each actor will seek to ensure that institutions are interpreted and are in effect revised in a manner that maximises its own competences. We do not have space to explore all the implications in this volume, but note that these arguments provide the basis for an exciting future research agenda. For example, we may expect that the degree of ambiguity of different parts of the Treaty text will vary, with important consequences for the ability of actors to change procedures through ex post bargaining.

In this volume, we adopt a narrower agenda. We begin by identifying two main avenues of interstitial institutional change. First, there is change in rules. Actors may bargain over the particulars of legislative decisions, creating informal institutions (or seeking formal judgements) to guide the day-to-day application of a particular higher-order formal rule, which is necessarily ambiguous. The informal or formal rules resulting from this bargaining process may have important consequences for the relative decision-making competences of the relevant actors (Farrell and Héritier 2003). Thus, we can expect competence-maximising actors to have an interest in bargaining for institutional changes that favour them rather than their rivals. They may also seek rulings from the ECJ that confirm their preferred interpretation of the rules rather than another interpretation in instances in which they stand a good chance of winning (or, at the least, suffer low costs for losing).

Second, there is choice over rules: actors may resort to 'procedural politics' (Jupille 2004) and engage in conflicts over the choice of a particular procedure. They may bargain over which of several possible procedures of decision-making is chosen in a given instance, and these conflicts may be settled by a formal Court ruling. They can use threats and promises to influence the choice over particular decision-making rules in the legislative process, so as to increase their own influence over policy outcomes. Over time, this will change the long-term framework through which specific areas of policy- and law-making are allocated to particular legal bases, so that the consequences of the Treaty for decision-making change.

Actors' success in pushing for institutional changes or institutional choices that strengthen their influence will depend on their bargaining 
strength vis-à-vis other actors; we develop this point in the next section. Over time, these bargaining interactions will lead to the instantiation of long-term expectations over mutual behaviour in informal institutions (Knight 1992; Farrell and Knight 2003; Stacey and Rittberger 2003). The formal texts of the Treaty will be supplemented by informal rules, or procedural politics. Both changes may be described as interstitial institutional change, i.e. change in institutions which occurs between Treaty reforms.

Finally, under particular circumstances, informal institutions and patterns of choice over procedures of decision-making may feed back into formal higher-order institutional change; that is, informal or formal institutional change at time $t$, or the selection of a particular procedural rules among several possible under one higher-order rule may directly affect Treaty revisions at time $t+1$. In the specific context of the EU, actors may seek with varying success during Treaty negotiations to formalise - or roll back - positional gains that have been achieved in the interstitial period between formal Treaty revisions. Because the existing institutions (including informal interpolations and procedural choice) form an effective status quo solution that will be maintained in the absence of unanimous member state agreement (Scharpf 1988), member states will face important constraints on their ability to reshape institutions which have evolved in ways that they would not have desired ex ante (Pierson 1996). Interstitial institutional change not only allows 'agents' to effectively renegotiate the institutions governing the relationship with their 'principals' at the level of everyday politics. In consequence it also provides an effective status quo ante for future formal negotiations among the principals, and thus feeds back into processes of Treaty change. Below, we discuss the mechanisms through which this is likely to happen; for further development, see Farrell and Héritier (2007) on the codecision process and Jupille (2007) on legal basis disputes.

\section{The Mechanisms of Institutional Change}

What drives these processes of interstitial institutional change? Our arguments are best located in that tradition of analysis that starts with a given institutional setting and asks how it may change as it is adapted to new circumstances. Thus, in a very broad sense, institutional rules serve both as explanatory factors and as explanandum in our analysis; the new rules are in an important sense conditioned on the old ones. This does not mean that our argument is circular - the institutions doing the explaining are different in kind and/or temporal location from the institutions being explained. ${ }^{5}$ Thus, our approach examines institutions in a more dynamic sense than arguments that see institutions as either reflections of state power relations, or as simple facilitators of state choice (see Caporaso 2007). Institutions change, in our argument, because of the incompleteness of contracts and the space that this creates for ex post bargaining processes. 
As stated above, we identify three mechanisms through which these conflicts over competences may translate into institutional change - the two forms of interstitial change, and the transformation of lower-level institutional changes into Treaty changes at a later juncture. Thus, we propose that conflicts over competences - whether they unfold through procedural politics or through the creation and change of informal institutions - will lead to interstitial institutional change, and will be a crucial determinant of EU political structures. They shape the day-to-day politics of decision-making, both in legislation and in policy formulation. And - as emphasised - under circumstances that we and our co-authors seek to document, interstitial changes may have long-lasting consequences for EU politics, up to and including changes in the EU's constituting Treaties. We are particularly interested in how interstitial changes affect the distribution of competences among the key actors in EU politics - the Council, the Commission, the European Parliament and, in a slightly different sense, the ECJ.

If the Treaty texts are incomplete contracts, and actors seek to maximise their influence over policy outcomes, what determines which actors are successful and which are unsuccessful in increasing their influence? We argue that the relative bargaining strength of actors - Council, Parliament and Commission - will dictate their respective abilities to shape both choice over rules and change in rules. The key determinants of bargaining strength are actors' relative abilities to make credible threats and withstand the credible threats of others. The effectiveness of credible threats depends on (1) the actions available to actors in the specific procedure of policy- or law-making in question, (2) the time horizons of the actors involved, (3) the direct sensitivity of the actors involved to failure of the policy measure in question, and (4) the justiciability of the matter (and previous rulings of the ECJ with regard to matters of this kind). ${ }^{6}$

We examine these factors in turn. First, we look at the actions that are available to actors in a given area of law-making or policy-making. The Treaty texts governing a particular area of law- or policy-making set broad parameters circumscribing the threats that actors can or cannot make in pursuit of informal institutional change. These parameters are broad - as already noted, the Treaty texts are incomplete contracts - but they do exist. To the extent that Treaty texts are construed as providing actors with the ability to block or to delay legislation or policy implementation, the texts increase the bargaining strength of those actors $v i s-\grave{a}$-vis other actors. If actors can credibly threaten to block or delay items of legislation that are important to other actors, they may be able to win long-term institutional concessions.

How then do we evaluate the relative bargaining strength of actors in procedures such as codecision, where both Parliament and Council have the formal possibility of blocking and/or delaying legislation? Here it is necessary to turn to the second and third factors, which measure not the ability of actors to issue credible threats, but their vulnerability to credible threats issued by others. 
The availability of a fall-back position or, put differently, sensitivity to failure may affect bargaining strength. Actors who are likely to suffer substantially in the event that agreement is not reached will be in a weaker bargaining position than actors who will not suffer substantially; the former will be more vulnerable to credible threats and less able to issue such threats themselves. Sensitivity to failure may be assessed in terms of the extent to which some political actors are more exposed to the electoral process than others. ${ }^{7}$ These actors will have more to lose from failure than actors that are less exposed, as they are more likely to be punished by the electorate for their failure to reach agreement. Thus, the European Commission is not exposed to direct elections, while elections to the European Parliament are usually 'second order contests' (Hix 1998: 52) in which voters seek to punish or reward the national government rather than to assess the performance of specific Members of the European Parliament, or of Parliament as a whole. In contrast, the Council represents the national governments of the member states, a group of politicians that is more likely to be assessed - and held responsible - for policy failures in national elections.

Third, time horizons play an important role. 'Impatient' actors (Pierson 1996; Rittberger 2000), who discount the future highly, will be in a weaker bargaining position than actors that are relatively time-insensitive because the former will be more vulnerable to others' threats to delay items of policy and legislation. Again, the Council and, in particular, the Presidency are disadvantaged in this regard. Under the current system, the Presidency of the Council rotates every six months among the member states, and there is a considerable amount of prestige bound up in having a successful Presidency in which many, and important, items of legislation are passed. This means that individual Council Presidencies have an incentive to make significant concessions in order to reach a deal with Parliament over items of legislation that are subject to the codecision rule. ${ }^{8}$

Finally, the relative ability of actors to appeal to the ECJ will affect their bargaining power in disputes over procedure. If a matter is justiciable, and the Court has a clear previous record of ruling in favour of one actor or another with regard to a particular kind of procedural dispute, the actor in question will have greater bargaining power vis-à-vis other actors in these disputes, even when it does not formally go to law. Other actors may reasonably fear they will find themselves bound by an unfavourable precedent if the matter goes to law. This allows more privileged actors to press for procedural gains that may then be instantiated in institutional change.

In cases where the actors press their claim and go to court, the ECJ may then issue an authoritative ruling, based on its interpretation of the relevant Treaty articles, which not only applies to the matter under dispute, but potentially sets a precedent for the ECJ's handling of future disputes of a similar character. 9 There is evidence that actors selectively seek out 'good' 
cases that they take to the ECJ so as to increase their competences or delimit the competences of another actor. ${ }^{10}$

The existing literature provides ample evidence to suggest that the ECJ has sought to maximise its competences over time, by increasing its scope to interpret the Treaty texts as a constitution that binds member states as well as Parliament and Commission (Mattli and Slaughter 1995; Stone Sweet 2000). However, because the ECJ's authority rests fundamentally on its powers of authoritative interpretation, it is to a certain extent limited by the texts that it interprets. Adapting Alec Stone Sweet's arguments (2000), we expect the ECJ to be most activist on points of interpretation where there is a relevant Treaty text to be interpreted, but where there are ambiguities within it, so that there are multiple legitimate possible interpretations. The ECJ's choice over possible interpretations of Treaty texts is further limited by its need to maintain legitimacy through some form of consistency in its rulings over time (Epstein and Knight 1999), and its desire to avoid unanimous censure from the member states that might lead them to limit its authority in subsequent Treaty revisions.

\section{Interstitial Change in Areas of Intersecting Decision-making in the EU}

Given the above theoretical arguments, the scope and role of interstitial institutional change will vary across different areas of intersecting decisionmaking competences in the EU. We do not attempt to create a detailed map of the different arenas of EU policy-making and law-making in this introductory article. Instead, we provide a more general overview of how conflicts over competence may occur in the making of both law and policy in a number of areas of shared decision-making.

First, within the legislative process, there are several different legislative procedures with shared powers, with differing consequences for the respective ability of Commission, Council and Parliament to affect outcomes. Each of these actors may be expected to push that legislation with ambiguous Treaty bases be adopted under a procedure that favours them (choice over rules) or negotiate an informal or formal rule that favours its institutional interests (change in rules). Thus, the European Parliament has successfully pushed for an effective right to confirm individual Commissioners by introducing informal rules. In disputes over comitology procedures, in which implementing powers are delegated to the Commission under the oversight of committees composed of national experts, the different forms of comitology procedures have been strongly contested because of their various implications for the respective authority of Commission and member states. Over time, the actor with delegated authority - the Commission - has consistently sought to maximise its discretion and minimise outside control, while the Council and Parliament have argued over whom the Commission should be responsible to - the member states alone, or the member states and Parliament together. 
Given the above, we ask:

a) When will shifts in the distribution of power within the decision-making process occur through interstitial institutional change?

b) When will these shifts be formalised in subsequent rounds of Treaty revision?

This article has, up to this point, presented a framework of analysis rather than a narrow set of hypotheses. The other articles in the volume draw upon this framework to create more tightly specified hypotheses, holding some of the variables that we discuss constant, while allowing variation in others. For example, as a first approximation, we might treat the vulnerability of the relevant actors - Parliament, Commission, Council - to threats of delay or breakdown as constant across issue areas, concentrating instead on how the actions that are available to actors and the possibility of recourse to the ECJ create variation in outcomes.

Under this tighter set of assumptions, we suggest that the bargaining strength of actors across a wide variety of issues in procedural politics will vary systematically according to the procedural tools available to actors in a given arena and the possible consequences of appealing to the ECJ.

First, ceteris paribus, the bargaining strength of actors will vary according to the options they have to delay or to block the making of policy and legislation. This argument has much in common with George Tsebelis' (2002) 'veto players' perspective; however, unlike Tsebelis, we apply this argument to the making of institutions, not policy. We predict that in arenas of decision-making where an actor has the ability neither to delay nor to block policy or legislation, that actor will have negligible bargaining strength. In arenas of decision-making where an actor has the ability to delay policy or legislation, but not to block it, that actor will have some bargaining power. In cases in which an actor has the ability to selectively block or delay policy or legislation, then it will have more bargaining power still. The respective bargaining strengths of actors will be instantiated in the informal or formal institutions that 'fill in' the incomplete areas or gaps of Treaty text so that variation in bargaining strength will be associated with variations in institutional outcomes. In the case of procedural politics it will be instantiated in the systematic choice of a particular procedure of decision-making that favours the institutional interests of stronger actors over others in the case of procedural politics.

Comparing areas of joint decision-making, we would, for example, expect to see significant differences between the informal institutions surrounding the cooperation process of law-making, and the informal institutions surrounding the codecision process. In the former, Parliament has only quite limited veto powers, while in the latter (especially post-Amsterdam) it has relatively extensive powers to veto legislation. Hence, ceteris paribus, we 
would expect Parliament to have had greater bargaining strength in conflicts over how to 'fill in the gaps' of the codecision procedure than it has had in the cooperation procedure. Hence, the informal institutions that structure relations in the codecision procedure should favour Parliament more than any cognate institutions structuring relations in the cooperation procedure. Indeed, the empirical evidence strongly suggests that the 'trialogues' and other institutions associated with codecision provide for a much greater share of the possible spoils than the rather less developed informal practices surrounding cooperation, let alone the toothless consultation procedure (Earnshaw and Judge 1996).

Second, third-party dispute resolution - the courts - may affect the bargaining strength of actors when they bargain over the selection of lowerorder rules. The ECJ's effect will vary across issues of contention depending on whether the issue is or is not justiciable at the ECJ and, if it is justiciable, what the likely judgement in a given case or set of related cases will be. Thus, bargaining over issues that are outside the ECJ's purview will be different from bargaining over issues where the relevant parties can appeal to the ECJ; furthermore the ECJ's pattern of rulings will have specific implications for bargaining outcomes.

We illustrate this through a comparison of choices over procedure in legislation and delegation, and conflicts over the interpretation of these procedures. First, we examine choice over appropriate procedures. As Jupille (2007) argues, ambiguities in the Treaty mean that many items of legislation might possibly be adopted under a number of possible procedures. A similar situation applies in the area of comitology, where any one of a number of different comitology procedures may be adopted for a particular area of delegated authority. In both contexts, the relevant actors Council, Parliament, Commission - are likely to bargain among themselves, each attempting to maximise its particular influence. However, despite these similarities, there will be variation in outcomes according to the pattern of ECJ rulings over time. In controversies over choice of legislative procedure, the ECJ may refer to existing Treaty texts, which are often ambiguous concerning the procedure to be applied to a given item of legislation. The ECJ may thus issue activist rulings that increase its effective authority, but which are unlikely to affect its legitimacy negatively or provoke unanimous disapproval from the member states. In contrast, we would expect a different pattern of ECJ rulings in controversies over choice of comitology procedure. Rather than ambiguity of the Treaty texts, there is a vacuum the Treaties hardly discuss comitology and provide virtually no basis for rulings as to which comitology procedure is appropriate under which circumstance, resulting in a much weaker position for the ECJ. In consequence, it will be cautious about issuing activist rulings that might be considered illegitimate by the member states, and will refrain, insofar as possible, from controversial substantive rulings over comitology procedures restricting member state choice. 
As a result, we predict that there will be systematic differences between the aggregate results of choice over legislative procedures, and the aggregate results of choice over comitology procedures. Specifically, we expect that the legislative procedures that are chosen will reflect the existing history of ECJ rulings and the interpretive frames (Stone Sweet and McCowen 2003) embodied in those rulings. Actors may credibly threaten to take an ECJ action when the choice of legislative base and procedure deviates little from that which the ECJ would prefer. In many instances, the mere threat of an ECJ action will suffice so long as it is credible, even if it is off the path of play. Thus, we predict there will be a mixed result, with the choice of procedure sometimes favouring the Council, sometimes Parliament, sometimes the Commission, according to the previous decisions made by the ECJ and the impact of these decisions on the bargaining games between Council, Parliament and Commission. Once beliefs about the appropriate legal bases applicable in ambiguous cases become sufficiently strongly established, they may reasonably be described as informal institutions.

In comitology, in contrast, there is little scope for actors to credibly threaten ECJ actions over choice of procedure. The Council has traditionally prevailed in fights over choice of procedure, despite Parliament's efforts to introduce reform. In part at least, this reflects the difficulty that Parliament would have in taking the Council to court: even though the Treaty has been amended so as to provide a more formal basis for comitology, there is scant basis in its text for the ECJ to decide which procedure should be applied under which circumstance. Furthermore, control over delegation is an especially sensitive area of EU politics for member states (see further, Bergström 2005). Accordingly the ECJ will have little interest in, or basis for, issuing activist rulings regarding choice of procedure that cut against the interests of the member states. We thus predict that the shadow of the court will play little to no role in bargaining over choice of procedure, and that the Council, which plays a preponderant role in the decision-making process, will usually be able to choose procedures of delegation that maximise its control over delegated powers, in the teeth of opposition from the Commission and, to the extent that it plays any role at all, Parliament. In consequence, the bulk of comitology procedures will favour the Council rather than other actors, and there will be relatively little scope for processes of interstitial institutional change that might undermine the Council's position.

Second, we examine disputes over the interpretation and application of procedures, once a specific procedure has been chosen. Concerning the controversies over the choice of procedures, differences in the role of the ECJ can be associated with differences in bargaining outcomes. Again, this will lead to observable variation in the bargaining power of actors across issue areas. In situations where the ECJ has previously consistently ruled to support an interpretation of procedure that favours one party, and does not favour another, we may expect the former party's bargaining strength to be 
substantially increased vis-à-vis the latter's. Even where the former party does not directly refer a case to the ECJ, it can credibly threaten to do so, and thus win concessions from the other party that meet its preferences over procedure. This should lead to ex ante predictable variation across issue areas. For example, in bargaining situations between the Council and Parliament, ceteris paribus, we expect to find Parliament in a weaker bargaining position vis-à-vis the Council in those procedural areas (such as comitology) where the ECJ has consistently refused to rule in favour of Parliament than in those procedural areas (respective roles of Council and Parliament in the legislative process) where the ECJ has sometimes ruled in favour of Parliament. These differences in bargaining strength will give rise to observable differences in bargaining results. Parliament should win more often, and with more substantial concessions, in procedural battles involving the latter kind of issues. The articles in this volume (in particular, Jupille 2007, and Bergström et al. 2007) offer significant empirical evidence supporting this prediction.

Finally, we enquire into the conditions under which interstitial institutional changes will be incorporated into subsequent Treaty revisions. Although we acknowledge - as argued in the existing scholarship on Intergovernmental Conferences (IGCs) - that the member states play a preponderant role in the process of Treaty change, we note that member states' power to respond to changing circumstances through Treaty change is limited by the unanimity requirement, and the fall-back position in cases of non-agreement (Tsebelis and Garrett 2001; Hix 2002). Member states must unanimously agree to any changes to the Treaty; if they cannot agree on change, the status quo ante continues to apply. As Hix (2002) observes, this has important implications for specific instances of institutional bargaining, but it has even more substantial consequences for longer term processes of institutional change in the EU. As Fritz Scharpf (1988) points out, the consequences of any unanimity rule depend crucially on the situation that ensues if unanimous agreement is not achieved. In the EU, the fall-back position is the existing Treaty text, as it has been renegotiated and effectively modified through processes of interstitial institutional change. This means, as argued above, that member states will be unable to reverse any gains that other actors - Commission, Parliament or ECJ make through the process of interstitial institutional change, unless they can reach unanimous agreement on institutional reforms that effect such a reversal.

This carries a number of important empirical implications. First, the Council's ability credibly to threaten Treaty change will vary with the ability of the member states to secure unanimity among themselves. In controversial issue areas (most likely areas in which there has been visible dissent in the previous round of Treaty revisions) it will be difficult for the Council credibly to threaten Treaty revisions. Thus, we may expect that Parliament and Commission will gain most in areas of procedural politics 
with a low prospect of the member states reaching a unanimous decision to respond through Treaty change.

Second, we may expect that in circumstances where (a) Parliament, Commission or ECJ are successful in bringing about interstitial institutional changes that favour their interests, (b) where the member states have no hope of reaching a unanimous decision to reverse these changes, and (c) where member states can substantially reduce transaction costs by formalising these changes in 'parchment' (Carey 2000), member states will be prepared to introduce Treaty changes that formalise previously existing informal practices. We further discuss these issues in our own contribution (Farrell and Heritiér 2007).

\section{Description of Contents}

The authors of the articles in this volume show how shifts in the distribution of competences take place interstitially, either on the basis of procedural politics, i.e. the contest about legal basis, or through the creation of informal rules to fill in ambiguities. They not only apply the arguments set out in this introductory article, but revise or extend them as appropriate.

The articles cover several major areas of intersecting decision-making rights among formal actors in the EU political process: the right of initiative, consultation with external actors, codecision, choice of legal basis, comitology, and confirmation of the Commission.

In the first article, Ann Rasmussen shows that the formal rules which vest legislative initiative in the Commission have been modified over time by informal institutional rules which grant effective clout to the Council and Parliament. However, she also shows that these informal rules were not formalised. In order to explain this, she argues that the likelihood of formalisation depends on the uncertainty of the informal institution, the costs of formalisation and the likely side-effects that formalisation would have. Rasmussen shows that the Council and Parliament are reluctant to incur the possible costs and side-effects of drastically changing existing relations between the three bodies and, therefore, limit themselves to changing the informal institutional rules governing legislative initiative, rather than seeking a formal reallocation of competences.

Pieter Bouwen's article on the Commission's consultation of civil society describes conflicts between the Commission and Parliament in formulating the institutional rules concerning consultation of civil society organisations. Using the theoretical framework developed above, Bouwen shows how Parliament, by withholding its approval of a Commission proposal, forced the latter to withdraw an informal institutional rule that Parliament considered to impinge upon its own consultative interactions with civil society.

Henry Farrell and Adrienne Héritier examine the sources and processes of institutional change in one important aspect of EU politics - the legislative procedure of codecision and show how interstitial change of institutions 
emerges between formal Treaty revisions and under specific conditions may be formalised in subsequent formal Treaty reforms. They develop two related models of Treaty change. First, a 'simple' model would predict that informal rules will be formalised in the Treaty text where all member states are in agreement, and will be rolled back when all member states oppose them; otherwise they will continue in existence at the informal level. Second, they lay out a more complex framework, under which actors who have effective veto powers in a related arena may make credible threats that allow them to press member states into formalising informal rules, provided that member states are not unanimously opposed to this formalisation.

Joseph Jupille in his contribution on the choice of legal basis argues that because different procedures give different degrees of influence to the various actors, the choice of legal basis is acutely political. This leads to interstitial bargaining over competencies in the shadow of the ECJ and, in some cases, requests to the Court to solve disputes, which may feed back into long-run institutional change, i.e. Treaty revisions.

Rule ambiguity and the role of the ECJ in interpreting incomplete contracts are at the centre of Leonor Moral Soriano's article. She analyses the role of the ECJ in conflicts over the vertical distribution of competences between the Union and member states. She focuses on the particular juridical mechanism of conflict resolution as a motor of interstitial change, but also raises the question of how Treaty revisions may be linked to vertical conflicts over the distribution of competences.

Fredrik Bergström, Henry Farrell and Adrienne Héritier analyse the interstitial change of institutional rules governing the comitology procedures. They start from a set of arguments about actors' preferences, and seek to explain how actors' ability to bargain successfully in order to advance these preferences has changed over time as a function of the particular institutional context. They show how actors use their bargaining power under given institutional rules at different points in time in order to shift the existing formal division between legislation and delegation and the rules governing delegation in their favour. The primary focus is on choice over procedure; the battles over whether or not delegation or legislation should be employed, but they also examine how changes in (comitology) procedures came about.

In the final empirical contribution Catherine Moury focuses on the process through which Parliament's power to appoint and invest the Commission emerged and developed over time. She argues that existing theories do not fully explain this development. According to intergovernmentalists (e.g., Moravcsik 1998), shifts of competences only reflect member states' preferences, which are exogenous. Given that several big member states were initially reluctant to allow an increase in Parliament's power to appoint the Commission and its President, how then can we explain the continuous increase of such power? She empirically explores whether and to what extent the theoretical explanation presented by us here (see also Farrell and Héritier 2003) is able to account for Parliament's institutional gains. 


\section{Acknowledgements}

The authors would like to thank the anonymous reviewers, Mark Pollack, Alberta Sbragia, and the other participants in this special issue, especially James Caporaso for comments on earlier versions of this article. They would also like to thank Michael Shackleton, Jean-Paul Jacqué, and Una O'Dwyer for sharing their knowledge of the codecision process, Amber Davis for editing, and Yannis Karagiannis for research assistance.

\section{Notes}

1. For the purposes of this article, we define an informal rule as a rule which is not subject to third-party dispute resolution.

2. Indeed we would argue that the theory of interstitial institutional change that we and our co-authors develop in this volume does not only hold for the European Union. Interstitial institutional change occurs in every polity where the original institutional provisions are ambiguous, which frequently is the case. Therefore we contend that our arguments are relevant to the institutional development of other polities, and especially those where higher-order rules are periodically revised.

3. See Jupille (2004) for an important exception.

4. The degree to which the text is incomplete is likely to vary across Treaty articles. The exploration of how variance in incompleteness may lead to variance in outcomes is an important agenda for future research.

5. We seek to understand how higher-order rules (together with other factors) impact lowerorder rules and vice versa in a temporally ordered sequence. For useful theoretical background, see Büthe (2002).

6. We thus seek to simplify slightly the account of bargaining strength in Héritier and Farrell (2003), while introducing the role of the ECJ.

7. To the extent that the fall-back position of an actor in case of a failure of the bargaining process is determined by other than institutional factors, exogenous factors play a role in determining the outcome of the negotiation process.

8. This disadvantage is likely to be redressed in part under the current proposal that the Council have a semi-permanent President.

9. The ECJ has occasionally issued rulings that have had dramatic consequences for actors' competences, as in the Isoglucose cases, which allowed the European Parliament to use the consultation procedure to delay legislation. (Cases 138 and 139/79 of 29 October 1980).

10. Interview with Commission Official, September 2001.

\section{References}

Ayres, Ian, and Robert Gertner (1992). 'Strategic Contractual Inefficiency and the Optimal Choice of Legal Rules', Yale Law Journal, 101:4, 729-73.

Bergström, Carl F. (2005). Comitology: Delegation of Powers in the European Union and the Committee System. Oxford: Oxford University Press.

Bergström, Carl-Fredrik, Henry Farrell, and Adrienne Héritier (2007). 'Legislate or Delegate? Bargaining over Implementation and Legislative Authority in the EU', West European Politics, 30:2, 338-66.

Büthe, Tim (2002). 'Taking Temporality Seriously: Modeling History and the Use of Narrative as Evidence', American Political Science Review, 96:3, 481-93.

Caporaso, James A. (2007). 'Promises and Pitfalls of an Endogenous Theory of Institutional Change: A Comment', West European Politics, 30:2, 392-404.

Carey, John M. (2000). 'Parchment, Equilibria, and Institutions', Comparative Political Studies, 33:6-7, 735-61. 
Earnshaw, David, and David Judge (1996). 'From Co-operation to Co-Decision: The European Parliament's Path to Legislative Power', in J. Richardson (ed.), European Union: Power and Policy Making. London: Routledge, pp. 96-127.

Epstein, Lee, and Jack Knight (1999). 'Mapping Out the Strategic Terrain: The Informational Role of Amici Curiae', in Cornell W. Clayton and Howard Gillman (eds.), Supreme Court Decision Making: New Institutionalist Approaches. Chicago: Chicago University Press, 215-35.

Farrell, Henry, and Jack Knight (2003). 'Trust, Institutions and Institutional Evolution: Industrial Districts and the Social Capital Hypothesis', Politics and Society, 31:4, 537-56.

Farrell, Henry, and Adrienne Héritier (2003). 'Formal and Informal Institutions under Codecision: Continuous Constitution-Building in Europe', Governance, 16:4, 577-600.

Farrell, Henry, and Adrienne Héritier (2007). 'Codecision and Institutional Change', West European Politics, 30:2, 285-300.

Hix, Simon (1998). 'The Study of the European Union: The "New Governance" Agenda and its Rivals', Journal of European Public Policy, 5:1, 38-65.

Hix, Simon (2002). 'Constitutional Agenda-Setting through Discretion in Rule Interpretation: Why the European Parliament Won at Amsterdam', British Journal of Political Science, 32:2, $259-80$.

Jupille, Joseph H. (2004). Procedural Politics. Issues, Influence, and Institutional Choice in the European Union. Cambridge: Cambridge University Press.

Jupille, Joseph (2007). 'Contested Procedures: Ambiguities, Interstices and EU Institutional Change', West European Politics, 30:2, 301-20.

Jupille, Joseph H., James A. Caporaso and Jeffrey Checkel (2003). 'Integrating Institutions: Rationalism, Constructivism, and the Study of the European Union', Comparative Political Studies, 36:1-2, 7-40.

Knight, Jack (1992). Institutions and Social Conflict. Cambridge: Cambridge University Press.

Mattli, Walter, and Anne-Marie Slaughter (1995). 'Law and Politics in the European Union: A Reply to Garrett', International Organization, 49:1, 183-90.

Moravcsik, Andrew (1997). 'Taking Preferences Seriously: A Liberal Theory of International Politics', International Organization, 51:4, 513-53.

Moravcsik, Andrew (1998). The Choice for Europe: Social Purpose and State Power Form Messina to Maastricht. Ithaca, NY: Cornell University Press.

Pierson, Paul (1996). 'The Path to European Integration: A Historical Institutionalist Analysis', Comparative Political Studies, 29:2, 123-63.

Rittberger, Berthold (2000). 'Impatient Legislators and New Issue Dimensions: A Critique of the Garrett-Tsebelis "Standard Version" of Legislative Politics', Journal of European Public Policy, 7:4, 554-75.

Scharpf, Fritz W. (1988). 'The Joint Decision Trap: Lessons From German Federalism and European Integration', Public Administration, 66:3, 239-78.

Shepsle, Kenneth A. (1989). 'Studying Institutions: Some Lessons from the Rational Choice Tradition', Journal of Theoretical Politics, 1:2, 131-47.

Stacey, Jeffrey, and Berthold Rittberger (2003). 'Dynamics of Formal and Informal Institutional Change in the EU', Journal of European Public Policy, 10:6, 858-83.

Stone Sweet, Alec (2000). Governing with Judges: Constitutional Politics in Europe. Oxford: Oxford University Press.

Stone Sweet, Alec, and Margaret McCown (2003). 'Discretion and Precedent in European Law', in Ola Wiklund (ed.), Judicial Discretion in European Perspective. Stockholm: Kluwer Law International, 84-115.

Tirole, Jean (1999). 'Incomplete Contracts: Where Do We Stand?', Econometrica, 67:4, 741-81.

Tsebelis, George (2002). Veto Players. How Political Institutions Work. Princeton, NJ: Princeton University Press.

Tsebelis, George, and Geoffrey Garrett (2001). 'The Institutional Foundations of Intergovernmentalism and Supranationalism in the European Union', International Organization, $55: 2,357-90$.

Williamson, Oliver (1975). Markets and Hierarchies: Analysis and Antitrust Implications. New York: Free Press. 
Copyright of West European Politics is the property of Routledge and its content may not be copied or emailed to multiple sites or posted to a listserv without the copyright holder's express written permission. However, users may print, download, or email articles for individual use. 